\title{
Associations between spiritual well-being and quality of life in Parkinson disease
}

\author{
Janis M. Miyasaki ${ }^{1}$, Benzi M. Kluger ${ }^{2}$, Stefan Sillau ${ }^{2}$, Maya Katz $^{3}$, Nicholas Galifianakis ${ }^{3}$, Lindsay P. Prizer ${ }^{4}$ \\ ${ }^{1}$ Parkinson and Movement Disorders Program, Department of Medicine, University of Alberta, Edmonton, Canada; ${ }^{2}$ Department of Neurology, \\ University of Colorado School of Medicine, Aurora, CO, USA; ${ }^{3}$ Department of Neurology, University of California, San Francisco, CA, USA; \\ ${ }^{4}$ Division of General Medicine and Geriatrics, Emory University School of Medicine, Atlanta, GA, USA \\ Correspondence to: Lindsay P. Prizer, PhD, MSW, LCSW. Emory University School of Medicine, 6 Executive Park, ${ }^{\text {st }}$ Floor, Atlanta, GA 30329, USA. \\ Email: lprizer@emory.edu. \\ Provenance and Peer Review: This article was commissioned by the editorial office, Annals of Palliative Medicine. The article did not undergo external \\ peer review. \\ Response to: Kilpatrick MM, Robinson MT. Addressing spiritual well-being as a means of improving quality of life in Parkinson disease. Ann Palliat \\ Med 2019. [Epub ahead of print].
}

Submitted Mar 04, 2020. Accepted for publication Mar 22, 2020.

doi: 10.21037/apm.2020.03.35

View this article at: http://dx.doi.org/10.21037/apm.2020.03.35

We thank Drs. Kilpatrick and Robinson for their comments. Regarding the diagnosis of patients, the majority of patients had a diagnosis of Parkinson disease (PD) (including PD dementia and Lewy Body Disease) in addition to a smaller number of patients with Parkinson plus disorders (progressive supranuclear palsy, multiple system atrophy and Corticobasal syndrome for a total of $11.5 \%$ in Standard Care and $12.3 \%$ in the Palliative Care group) (1). Given many patients have an alternative diagnosis after many years of follow-up (less than $60 \%$ accuracy of diagnosis), we do not believe that generalizability is limited due to the mixed population (2). In clinical practice, neurologists and other providers will be faced with a patient with parkinsonism that is most likely PD, but over time may have an alternative diagnosis.

All patients completed all quality of life questionnaires since it is not clear which quality of life instruments are valid in a palliative $\mathrm{PD}$ population.

While we excluded those with immediate palliative needs, this is based on an ethical concern that delaying access to palliative care would be to the detriment of our participants. Further, randomizing a palliative or hospice population may be also misleading since those "accepting" hospice care may either have higher spiritual distress or be more open to palliative approaches.

We agree that identifying spiritual distress is important. We are not clear that those with most spiritual distress will have advanced illness. The existential questions of "why has this happened to me?", "how can I carry on?", "how can I find hope?" are not exclusive to the most advanced and may in fact, be more acute in those newly diagnosed, and therefore less motor impaired. As demonstrated by our work, those without spiritual distress report higher quality of life, lower anxiety, lower depression, fewer non-motor symptoms, reduced palliative symptoms and less prolonged grief. This provides support for the presence of spiritual care providers in Neuropalliative care teams.

\section{Acknowledgments}

Funding: None.

\section{Footnote}

Conflicts of Interest: The authors have no conflicts of interest to declare.

Ethical Statement: The authors are accountable for all aspects of the work in ensuring that questions related to the accuracy or integrity of any part of the work are appropriately investigated and resolved.

Open Access Statement: This is an Open Access article 
distributed in accordance with the Creative Commons Attribution-NonCommercial-NoDerivs 4.0 International License (CC BY-NC-ND 4.0), which permits the noncommercial replication and distribution of the article with the strict proviso that no changes or edits are made and the original work is properly cited (including links to both the formal publication through the relevant DOI and the license). See: https://creativecommons.org/licenses/by-nc$\mathrm{nd} / 4.0 /$.

Cite this article as: Miyasaki JM, Kluger BM, Sillau S, Katz M, Galifianakis N, Prizer LP. Associations between spiritual wellbeing and quality of life in Parkinson disease. Ann Palliat Med 2020;9(3):1288-1289. doi: 10.21037/apm.2020.03.35

\section{References}

1. Kluger BM, Miyasaki J, Katz M, et al. Comparison of Integrated Outpatient Palliative Care With Standard Care in Patients With Parkinson Disease and Related Disorders: A Randomized Clinical Trial. JAMA Neurol 2020. [Epub ahead of print].

2. Adler CH, Beach TG, Hentz JG, et al. Low clinical diagnostic accuracy of early vs advanced Parkinson disease: clinicopathologic study. Neurology 2014;83:406-12. 